Check for updates

Cite this: RSC Adv., 2017, 7, 54188

Received 17th September 2017 Accepted 13th November 2017

DOI: 10.1039/c7ra10313a

rsc.li/rsc-advances

\section{Characterization of uranium in the extracellular polymeric substances of anaerobic granular sludge used to treat uranium-contaminated groundwater}

\author{
Hailing Zhang, ${ }^{a}$ Mengxi Cheng, ${ }^{a}$ Weidong Liu, ${ }^{a}$ Fengyu Huang, ${ }^{b}$ Huanhuan Ding, ${ }^{a}$ \\ Shicheng Li, ${ }^{a}$ Wei Guo, ${ }^{a}$ Yongpeng Wang ${ }^{\text {DD }}{ }^{* a}$ and Hexiang Huang ${ }^{* a b}$
}

Anaerobic granular sludge (AnGS) has been proven to be long-term effective for $U(\mathrm{VI})$ removal and can be used as an inoculum for permeable reactive barriers, which is an innovative technology for remediation of uranium-contaminated groundwater. Considering their great ability in biosorption and bioreduction to common metal ions, extracellular polymeric substances (EPS) should play an important role in $U(\mathrm{VI})$ removal and also in maintaining bioactivity of the AnGS due to toxicity accompanied with uranium. However, the roles of the EPS of AnGS in the uranium immobilization process are not clear. In this study, batch experiments were carried out by treating synthetic uranium-contaminated groundwater with AnGS, and uranium in EPS was extracted using four different methods. Moreover, speciation of uranium in EPS by filtration and inductively coupled plasma with mass spectroscopy and the reaction between isolated EPS and uranyl sulphate solution in a $\mathrm{NaHCO}_{3}$ medium were investigated. The results showed that about $12-16 \%$ of the total uranium immobilized by AnGS (extracted by the cation exchange resin (CER) method at $600 \mathrm{rpm}$ for $1 \mathrm{~h}$ ) was found to be present in EPS in its soluble ionic and particulate forms. For EPS-associated uranium obtained by the CER method, particulate uranium was proven to be the main form with sizes ranging from $24.7 \mathrm{~nm}$ to $171.3 \mathrm{~nm}$. In the process of uranium immobilization using EPS isolated from non-reacted AnGS, both biosorption and bioreduction were involved. The findings of this study imply the important roles of EPS in the immobilization of uranium in groundwater using AnGS.

\section{Introduction}

Uranium mining and mine tailings cause uranium contamination to adjacent groundwater, where uranium levels have been reported to be as high as $50 \mathrm{mg} \mathrm{L}^{-1}$. $^{1}$ Significant concerns regarding uranium behavior and remediation have been raised due to the hazardous nature of uranium related to its synchronous chemical toxicity and radiotoxicity. Uranium is mainly present as soluble hexavalent uranium $(\mathrm{U}(\mathrm{vI}))$ and insoluble tetravalent uranium (U(Iv)) in the environment. In groundwater, $\mathrm{U}(\mathrm{vI})$ migrates mostly in the form of uranyl ion $\left(\mathrm{UO}_{2}{ }^{2+}\right)$ or uranyl carbonate complexes (e.g. $\left.\mathrm{UO}_{2}\left(\mathrm{CO}_{3}\right)_{2}{ }^{2-}\right){ }^{2}$ The transformation of $\mathrm{U}(\mathrm{vI})$ can be accomplished by some microorganisms. A number of cases of the reduction of soluble $\mathrm{U}(\mathrm{vI})$ to insoluble $\mathrm{U}(\mathrm{rv})\left(\right.$ e.g. $\left.\mathrm{UO}_{2}\right)$ catalyzed by microorganisms, such as sulfate- or metal-reducing bacteria, have been reported. Indeed, microbial reduction has been widely proven as a costeffective and promising bioremediation strategy for the

anstitute of Materials, China Academy of Engineering Physics, Jiangyou, Mianyang, Sichuan, 621907, China. E-mail: wangyongpeng@caep.cn

${ }^{b}$ Mianyang Yijing Anti Radiation Technology Co., LTD, Jiangyou, Mianyang, Sichuan, 621907, China.E-mail:weiwei@caep.cn treatment of uranium-contaminated groundwater. ${ }^{3-5}$ Besides the abovementioned pure cultures, mixed cultures, such as anaerobic granular sludge (AnGS), have also been proven longterm effective for the reduction of $\mathrm{U}(\mathrm{vI})$, which have been inoculated to sand column reactors. ${ }^{6,7}$ Hence, a permeable reactive barrier inoculated with AnGS will be very beneficial for future in situ remediation of uranium-contaminated groundwater due to its convenient maintenance and cost. Moreover, AnGS will also act as an inhabitant in groundwater systems, affecting the $\mathrm{U}(\mathrm{vI})$ migration behavior.

Extracellular polymeric substances (EPS), located in the interspaces of bacteria inside the anaerobic granular sludge, have been proven to be important for maintaining the structural and functional integrity of AnGS aggregates. EPS are considered to have a strong influence on the migration and fate of many substances. First, EPS possess abundant functional groups and can immobilize large substances through biosorption or chelation. Many kinds of substances, including phosphorus, ${ }^{8}$ sulfanilamide, ${ }^{9}$ carbon nanotubes ${ }^{10}$ and some minerals, ${ }^{11,12}$ have been detected in EPS. Moreover, because of their excellent chelation ability, EPS can also act as a template for mineral nucleation and induce the formation of minerals such as calcite ${ }^{13}$ and struvite. ${ }^{14}$ Furthermore, EPS produced by some 
metal-reducing bacteria have been demonstrated to contribute to the reduction of ferrous iron, ${ }^{15}$ silver ions, ${ }^{16,17}$ and U(vI). ${ }^{18}$

As a typical pollutant, uranium has been found to be immobilized by EPS of some anaerobic microbes through biosorption, biomineralization or bioreduction. For example, the EPS of Citrobacter sp. is thought to be involved in the biomineralization process of $\mathrm{U}(\mathrm{vI}) .{ }^{19}$ The high biosorption capacity of EPS extracted from the anaerobic-activated sludge towards $\mathrm{U}(\mathrm{vI})$ has been proven by Yuan et al. ${ }^{20}$ Cao et al. $(2011)^{18}$ first reported the significant contribution of bioreduction of the EPS of Shewanella sp. in HRCR-1 to U(vI) immobilization, and it was considered that the extracellular $\mathrm{U}(\mathrm{vI})$ reduction was most probably caused by the redox active ccytochromes present in the EPS. ${ }^{21}$ Microbe species in AnGS are abundant, and several U(vI)-reducing bacteria have been identified to be inhabited in it. ${ }^{22,23} \mathrm{U}(\mathrm{vI})$-reduction was accomplished through an extracellular electron transfer by these functional microbes. Hence, the EPS matrix contains some electrochemically active substances and probably U(vI)reducing active enzymes released by cell autolysis. Then, in the remediation process of uranium-containing groundwater using AnGS, the contributory factors of EPS for uranium immobilization may be numerous and complicated, and biosorption, biomineralization, and bioreduction are likely to be involved. Hence, uranium present in EPS was predicted to be complex such as soluble $\mathrm{U}(\mathrm{vI})$ ions $\left(\right.$ e.g. $\mathrm{UO}_{2}{ }^{2+}, \mathrm{UO}_{2}\left(\mathrm{CO}_{3}\right)_{2}{ }^{2-}$ etc.), $\mathrm{U}(\mathrm{vI})$-phosphate precipitates (the product of adsorbed phosphate and $\mathrm{UO}_{2}{ }^{2+}$ ), or also U(Iv) precipitates. However, the chemical forms of extracellular uranium and their contents in EPS are still unclear. Therefore, a deeper insight into the characteristics, such as actual forms and contents, of uranium in EPS is desirable.

Regarding the two most probable states of the extracellular uranium, the soluble and particulate forms, different characterization methods are needed. To quantify the extracellular uranium content, a traditional extraction method has to be used. While for the accurate content of extracellular uranium, besides the previously reported influencing factors (e.g. the extraction efficiency of extracellular uranium, the leakage of intracellular uranium, etc), it is also necessary to evaluate the redissolution of insoluble U(Iv) during the extraction process. For the extracellular uranium in the particulate form, little information (such as the chemical composition of the minerals, the mineral fraction, and the valence states of uranium inside the minerals) is available.

The main objective of this study was to characterize uranium in the EPS of AnGS, which was applied for the immobilization of uranium in groundwater. The extracellular uranium content and mineral fraction and the re-dissolution of insoluble U(Iv) during various EPS extraction processes were investigated. Considering the probable roles of EPS in uranium bioreduction, the reduction of $\mathrm{U}(\mathrm{vI})$ to $\mathrm{U}(\mathrm{Iv})$ minerals by single EPS extracted from AnGS was also explored. The present study will provide great reference value for better understanding the mechanism of uranium removal from groundwater in microbial remediation systems and will be beneficial for guiding related uranium remediation practices.

\section{Materials and methods}

\subsection{Batch experiments for remediation using AnGS}

The remediation of uranium-contaminated groundwater using AnGS was carried out in the batch mode to investigate the immobilization of uranium by microbial cells and EPS. The experiments were conducted in $160 \mathrm{~mL}$ serum bottles using $100 \mathrm{~mL}$ of synthetic uranium-contaminated groundwater (minerals solution, $\mathrm{NaHCO}_{3}$, and $\mathrm{U}(\mathrm{vI})$ ) and $60 \mathrm{~mL}$ headspace. The mineral solution contained $\left(\mathrm{mg} \mathrm{L} \mathrm{L}^{-1}\right)^{23} \mathrm{NH}_{4} \mathrm{HCO}_{3}, 5$; $\mathrm{K}_{2} \mathrm{HPO}_{4}, 2 ; \mathrm{MgCl}_{2}, 2.1 ; \mathrm{Ca}(\mathrm{OH})_{2}, 1$; yeast extract, 0.33 and a trace element solution ( $\left.\mu \mathrm{g} \mathrm{L} \mathrm{L}^{-1}\right): \mathrm{H}_{3} \mathrm{BO}_{3}, 0.5 ; \mathrm{FeSO}_{4} \cdot 7 \mathrm{H}_{2} \mathrm{O}, 28$; $\mathrm{ZnSO}_{4} \cdot 7 \mathrm{H}_{2} \mathrm{O}, 1.1 ; \mathrm{CuSO}_{4} \cdot 5 \mathrm{H}_{2} \mathrm{O}, 1.6 ; \mathrm{MnSO}_{4} \cdot \mathrm{H}_{2} \mathrm{O}, 2.5 ;\left(\mathrm{NH}_{4}\right)_{6}-$ $\mathrm{Mo}_{7} \mathrm{O}_{24} \cdot 4 \mathrm{H}_{2} \mathrm{O}, 2.0 ; \mathrm{KAl}(\mathrm{SO} 4)_{2} \cdot 12 \mathrm{H}_{2} \mathrm{O}, 1.75 ; \mathrm{CoSO}_{4} \cdot 7 \mathrm{H}_{2} \mathrm{O}, 23.6$; $\mathrm{NiSO}_{4} \cdot 6 \mathrm{H}_{2} \mathrm{O}, 1.13 ; \mathrm{Na}_{2} \mathrm{SeO}_{3} \cdot 5 \mathrm{H}_{2} \mathrm{O}, 1 ; \mathrm{Na}_{2} \mathrm{WO}_{4} \cdot 2 \mathrm{H}_{2} \mathrm{O}, 5.2$; and EDTA, 10. The minerals solution was boiled for $10 \mathrm{~min}$ and sparged with $\mathrm{N}_{2}$ to remove the dissolved oxygen. After cooling down to room temperature, $1 \mathrm{~g} \mathrm{~L}^{-1} \mathrm{NaHCO}_{3}$ was dosed to adjust the $\mathrm{pH}$ to 7.0. Then, a $10 \mathrm{mM}$ stock solution of uranyl sulfate (99.99\% $\mathrm{UO}_{2} \mathrm{SO}_{4} \cdot 3 \mathrm{H}_{2} \mathrm{O}$ obtained from Hubei Chushengwei Chemical Co., Ltd, China) and AnGS were successively added to the medium to a final $\mathrm{U}(\mathrm{vI})$ mass concentration of $100 \mathrm{mg} \mathrm{L}^{-1}$ and VSS concentration of $2000 \mathrm{mg} \mathrm{L}^{-1}$ (VSS: volatile suspended solids). The bottles were sparged with $\mathrm{N}_{2}$ to further remove the remaining oxygen and then sealed with butyl rubber stoppers and aluminum tear-off seals. The temperature was controlled at $25 \pm 1{ }^{\circ} \mathrm{C}$. In the time course of 13 days, a $1 \mathrm{~mL}$ mixed solution was taken at certain intervals and centrifuged at $8000 \mathrm{rpm}$ for 5 min to determine $\mathrm{U}(\mathrm{vI})$ in the supernatant. After the reactions, $10 \mathrm{~mL}$ of the mixed solution was used for EPS extraction and $2 \mathrm{~mL}$ for the sequential extraction of uranium in the sludge. The batch test was repeated three times.

The AnGS was stored anaerobically at $4{ }^{\circ} \mathrm{C}$ prior to the experiments, which was obtained from a full-scale up-flow anaerobic sludge blanket (UASB) reactor (Hefei, Anhui, China) treating starch wastewater and with a VSS content of $65 \%$, moisture content of $94.9 \%$, and specific acetoclastic methanogenic activity of $350 \mathrm{mg}$ COD per $\mathrm{g}$ VSS per day. Prior to its addition, the sludge granules were washed with de-ionized water.

\subsection{EPS extraction}

Herein, four methods (sonication, EDTA, heating, cation exchange resin (CER), and a control method (centrifugation)) were used to extract the EPS from AnGS with immobilized uranium. As all the EPS extraction processes were carried out in an anaerobic glove box $\left(99.9 \% \mathrm{~N}_{2}\right)$, the centrifugation, sonication, EDTA, and CER methods were conducted at room temperature. To adequately extract the EPS, the sludge granules were first crushed and ground to flocs and suspended with a $100 \mathrm{mM}$ anaerobic $\mathrm{NaCl}$ solution (previously boiled and sparged with $\mathrm{N}_{2}$ ) to the original volume. After this, $10 \mathrm{~mL}$ of the sludge solution was harvested and centrifuged at $8000 \mathrm{rpm}$ for $5 \mathrm{~min}$. Then, the sludge pellets were washed twice with the $100 \mathrm{mM}$ anaerobic $\mathrm{NaCl}$ solution to remove any residual soluble substances in the media. Subsequently, the pellets were re- 
suspended with $10 \mathrm{~mL}$ of a $100 \mathrm{mM}$ anaerobic $\mathrm{NaCl}$ solution (or $2 \%$ anaerobic EDTA solution during EDTA extraction). The control method was performed using a two-step centrifugation process: at first, centrifugation was carried out at $10000 \mathrm{rpm}$ for $10 \mathrm{~min}$, and subsequently, the supernatant was centrifuged at $14510 \mathrm{rpm}$ (equivalent to $20000 \mathrm{~g}$ ) for $20 \mathrm{~min} .^{11,12}$ Sonication extraction was performed for $5 \mathrm{~min}$ or $10 \mathrm{~min}$ at $150 \mathrm{~W}$. For the EDTA extraction method, the sludge pellets re-suspended in an EDTA solution were kept for $2 \mathrm{~h}$ to extract the EPS. For the heating extraction process, the sludge mixture was heated at $60{ }^{\circ} \mathrm{C}$ for $20 \mathrm{~min}$ or at $80{ }^{\circ} \mathrm{C}$ for $10 \mathrm{~min}$ in a water bath. For the CER procedure, the extraction process was conducted in a $50 \mathrm{~mL}$ beaker with $70 \mathrm{~g}$ resin per $\mathrm{g}$ VSS of CER (DOWEX MARATHON C, $\mathrm{Na}^{+}$-form, 20-50 mesh, Sigma-Aldrich) with the extraction times of $1 \mathrm{~h}$ or $2 \mathrm{~h}$ at $600 \mathrm{rpm}^{24}$ Thereafter, the suspensions were centrifuged at $10000 \mathrm{rpm}$ for $10 \mathrm{~min}$ and subsequently at $14510 \mathrm{rpm}$ for $20 \mathrm{~min}$, and the supernatant was obtained without further treatment, withholding the uranium precipitates.

In addition, to explore the re-dissolution of insoluble $\mathrm{U}(\mathrm{Iv})$ during the EPS extraction, some amount of biologically reduced uranium, instead of the sludge, was used to repeat the EPS extraction procedure. The biologically reduced uranium was prepared according to the literature with a slight modification. ${ }^{25}$ The washed and crushed AnGS (the VSS concentration of $2000 \mathrm{mg} \mathrm{L}^{-1}$ ) was suspended in $100 \mathrm{~mL}$ of the mineral solution (the same as used in the batch tests) in a $160 \mathrm{~mL}$ serum bottle, amended with $2 \mathrm{~g} \mathrm{~L}^{-1} \mathrm{NaHCO}_{3}, 400 \mathrm{mg} \mathrm{L}^{-1}$ uranyl sulfate, and $20 \mathrm{mM}$ acetate, and incubated at $30{ }^{\circ} \mathrm{C}$ under anaerobic conditions. At day 4, the sludge flocs were obtained and washed twice with $100 \mathrm{mM} \mathrm{NaHCO}$ buffer to remove any loosely absorbed $\mathrm{U}(\mathrm{vI})$. Then, the pellet was incubated in $1 \mathrm{M} \mathrm{NaOH}$ for $1 \mathrm{~h}$ to dissolve the cell membranes and proteins. The suspension was then centrifuged and washed four times with $1 \mathrm{M}$ $\mathrm{NaHCO}_{3}$ to remove the remaining $\mathrm{NaOH}$ and any complexed $\mathrm{U}(\mathrm{vI})$. Finally, the pellet was sufficiently rinsed with deionized water until no $\mathrm{U}(\mathrm{vI})$ could be detected; this resulted in the formation of a purified U(Iv) solid. Then, the U(Iv) solid was resuspended with a $100 \mathrm{mM}$ anaerobic $\mathrm{NaCl}$ solution and divided into several aliquots to repeat the EPS extraction procedure. After centrifugation, the uranium concentration in the extracts was detected. The re-dissolution extent of insoluble U(Iv) was evaluated as the ratio of uranium in the extracts to total uranium in the solution.

\subsection{Chemical analysis}

All chemicals used in this study were of analytical grade. The concentrations of total uranium (TU) in the supernatant, EPS $\left(\mathrm{TU}_{\mathrm{EPS}}\right)$ or sludge $\left(\mathrm{TU}_{\text {sludge }}\right)$ were analyzed by inductively coupled plasma with mass spectroscopy (NEXION 350, Perkin Elmer), and all the samples were acidified using $5 \% \mathrm{HNO}_{3}$ as previously described. The VSS of the AnGS was measured according to a standard method. ${ }^{26}$ The extraction efficiency was analyzed by the total concentration of carbohydrates, proteins, humic substances, and nucleic acids in the EPS extracts, which was determined as previously described..$^{24}$
The fractionation of uranium in the AnGS before and after uranium immobilization reaction was performed according to the literature, ${ }^{6,7}$ with successive extractions of anaerobic MilliQ water (overnight), anaerobic $\mathrm{NaHCO}_{3}$ (1 M, overnight), and $\mathrm{HNO}_{3}(10 \%, 4 \mathrm{~h})$, representing the water soluble $\mathrm{U}(\mathrm{vI})$, adsorbed/complexed $\mathrm{U}(\mathrm{vI})$, and insoluble U(IV), respectively.

\subsection{Quantification of the mineral fraction of uranium in the EPS extracts}

Herein, two methods were used to quantify the mineral fraction of uranium in the EPS extracts. For the relatively large EPSassociated uranium particles (micron-size), a microporous membrane with a pore size of $0.22 \mu \mathrm{m}$ was used to differentiate the soluble and particulate uranium in the EPS extracts as this pore size was proven to be efficient to intercept minerals with sizes ranging from several microns to tens of microns. ${ }^{\mathbf{1 1 , 1 2 , 2 7}}$ To accurately quantify the EPS-associated uranium in its particulate form $(>0.22 \mu \mathrm{m})$, both sonication $(10 \mathrm{~min}$ at $150 \mathrm{~W})$ and CER ( $1 \mathrm{~h}$ at $600 \mathrm{rpm})$, which have been proven to cause a low extent of $\mathrm{U}(\mathrm{Iv})$ re-dissolution in the subsequent manuscript, have been chosen to perform the EPS extraction as abovementioned. After the extraction, about $30 \mathrm{~mL}$ of the EPS samples were filtered through $0.22 \mu \mathrm{m}$ cellulose nitrate membranes, and the initial filtrate was discarded. The membranes were previously saturated by uranyl ions by soaking in a sufficient $50 \mathrm{mg} \mathrm{L}^{-1}$ uranyl sulfate solution and then rinsed with large amounts of MilliQ water. The difference between the uranium content in the EPS solution before and after filtration was evaluated to be the mineral fraction of uranium in the EPS $(>0.22 \mu \mathrm{m})$. Moreover, six experiments for sonication and CER extraction were performed.

As some nano-sized colloidal uranium may not be intercepted by the membrane, the EPS extracts after $0.22 \mu \mathrm{m}$ filtration were analyzed using ICP-MS (NEXION 350, Perkin Elmer) in the single particle mode. In the single particle mode, the signal of the soluble uranyl ions was obviously different from the signal of the uranium-containing particles. The mineral fraction of the EPS-associated uranium within the EPS extracts after $0.22 \mu \mathrm{m}$ filtration was evaluated by the difference between the total uranium concentration in EPS (acidified in $5 \% \mathrm{HNO}_{3}$ ) and the concentration of soluble uranium ions. Herein, six experiments for sonication and CER extraction were performed.

On the other hand, for the characterization of the size distribution of the nano-sized uranium particles, a series of silver nanoparticles with known diameters and particle concentrations (Citrate NanoXact ${ }^{\mathrm{TM}}$ Silver, nanoComposix Inc.) were used as the standard particles. Moreover, one colloidal particle could be ionized in a plasma torch to be a flash of ions and was displayed as a transient signal to be detected by MS. The signal intensity presents the particle size, and the flash frequency accounts for the particle concentration.

\subsection{U(vI) immobilization using EPS in a $\mathrm{NaHCO}_{3}$ medium}

The EPS, used to determine the U(vI) immobilization, were isolated from the original AnGS (without reaction with $\mathrm{U}(\mathrm{vI})$ ) using CER extraction (600 rpm for $1 \mathrm{~h}$ in an ice bath). Then, the 
crude EPS filtered through the $0.22 \mu \mathrm{m}$ membrane was purified by dialysis (1000 MWCO, $24 \mathrm{~h}$, anaerobic water). ${ }^{16,18}$ After removing the ions and small molecules, the EPS was divided into two aliquots and separately placed in dialysis tubing (1000 MWCO) against a $\mathrm{UO}_{2} \mathrm{SO}_{4}$ solution $\left(25 \mathrm{mg} \mathrm{U} \mathrm{L} \mathrm{L}^{-1}, 1 \mathrm{~g} \mathrm{~L}^{-1}\right.$ $\mathrm{NaHCO}_{3}$ ) for $24 \mathrm{~h}$. To estimate the respective contribution of adsorption and reduction to $\mathrm{U}(\mathrm{vI})$ immobilization, the reaction process was conducted under two different conditions: anaerobic and aerobic. The anaerobic reaction was carried out in an anaerobic glove box $\left(99.9 \% \mathrm{~N}_{2}\right)$, whereas the aerobic reaction was performed under feeble and intermittent aeration conditions. The $\mathrm{U}(\mathrm{vI})$ concentrations in the bulk in the beginning (the dialysis tubing was previously immerged in the bulk and saturated with uranyl ions, and then, the EPS was injected), at $12 \mathrm{~h}$, and at $24 \mathrm{~h}$ were measured. The decrease in the aqueous $\mathrm{U}(\mathrm{vI})$ concentration in the anaerobic reaction was attributed to both $\mathrm{U}(\mathrm{VI})$ adsorption and $\mathrm{U}(\mathrm{vI})$ reduction by EPS, whereas the aqueous $\mathrm{U}(\mathrm{vI})$ removed after the whole aerobic reaction was mainly caused by adsorption. Under aerobic conditions, uranium reduction could also inevitably occur. However, the apparent reduction amount of uranium under aerobic conditions should be rather low. Subsequently, the U(vi) reduction was determined by the difference between the abovementioned two reactions. The $\mathrm{U}(\mathrm{vI})$ immobilization process was repeated in triplicate.

\section{Results and discussion}

\subsection{Uranium immobilization using AnGS}

The time course of $\mathrm{U}(\mathrm{vr})$ immobilization by AnGS without external electron donors is shown in Fig. 1. The results indicated that the concentration of $\mathrm{U}(\mathrm{vI})$ in the supernatant decreased constantly and became stable after day 10, and a removal efficiency of above $97 \%$ was achieved.

The uranium fraction in the AnGS, before and after the reaction, extracted by water, $\mathrm{NaHCO}_{3}$ and $\mathrm{HNO}_{3}$ are shown in Table 1 . The high uranium recovery indicates the effectiveness of this method. Since natural uranium exists in starch wastewater, a little uranium is already present in the original AnGS,

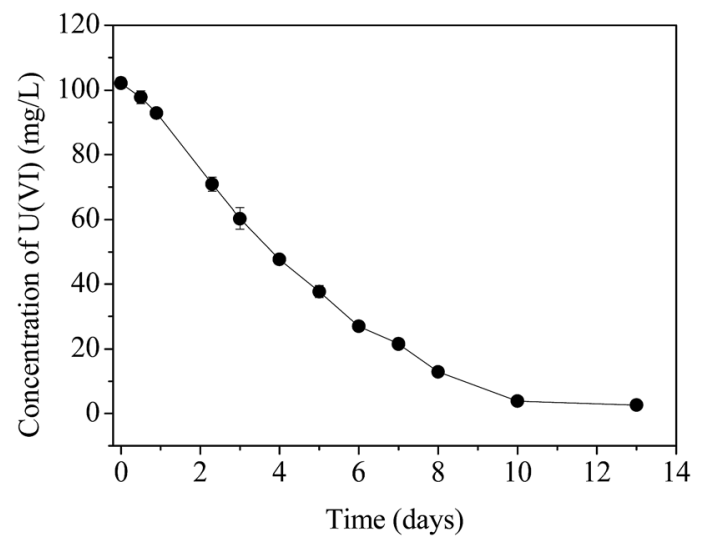

Fig. 1 The time course of uranium removal using AnGS without an external electron donor. with a content of $0.06 \pm 0.01 \mathrm{mg} \mathrm{U}$ per g SS. After the uranium immobilization reaction, the content of uranium in the sludge increased to $29.6 \pm 2.8 \mathrm{mg} \mathrm{U}$ per $\mathrm{g}$ SS. At the start point of the reaction and at day 13 , the absorbed $\mathrm{U}(\mathrm{vI})$ (e.g. $\mathrm{U}(\mathrm{vr})$ ions and $\mathrm{U}(\mathrm{vr})$ phosphate minerals), extracted by both water and $\mathrm{NaHCO}_{3}$, accounted for about $62.5 \%$ and $44.6 \%$, respectively. While $\mathrm{HNO}_{3}$ can extract about $37.5 \%$ and $55.4 \%$ uranium for the two reactionpoint sludge, which represent the reduced uranium-U(Iv) compounds. ${ }^{6}$ The results illustrate that the microorganisms capable of reducing $\mathrm{U}(\mathrm{vI})$, located in the AnGS, can effectively reduce $\mathrm{U}(\mathrm{vI})$ with an endogenous substrate. Furthermore, a higher $\mathrm{U}(\mathrm{rv})$ fraction implies that the activity of $\mathrm{U}(\mathrm{vI})$ reduction in the microorganisms was increased when they faced a high $\mathrm{U}(\mathrm{vI})$ content. In addition to biosorption, the bioreduction of $\mathrm{U}(\mathrm{vI})$ by AnGS occurred in the U(vI) removal process.

\subsection{Uranium content in the EPS}

The total uranium contents of the EPS solutions extracted from AnGS using different methods were found to be largely dependent on the EPS extraction efficiency and the re-dissolution extent of insoluble $\mathrm{U}(\mathrm{Iv})$ during the extraction process, as shown in Table 2 and Fig. 2 and 3. The TU contents in the EPS obtained from the control and sonication methods were low, which was consistent with their low EPS extraction efficiencies. Noticeably, the values of $\mathrm{TU}_{\mathrm{EPS}} / \mathrm{TU}_{\text {sludge }}\left(\mathrm{TU}_{\text {sludge }}=29.5 \mathrm{mg} \mathrm{U}\right.$ per g SS) obtained by both heating methods $\left(60^{\circ} \mathrm{C}\right.$ for $20 \mathrm{~min}$ and $80^{\circ} \mathrm{C}$ for $\left.10 \mathrm{~min}\right)$ were low $(2.06 \%$ and $1.20 \%$, respectively) although a relatively high EPS content (Table 2) was extracted from the sludge. D'Abzac et al. (2010) ${ }^{11}$ and Bourven et al. $(2011)^{12}$ have reported low mineral contents in heat-treated EPS extracted from AnGS and activated sludge. Therefore, the low $\mathrm{TU}$ content may also be attributed to the precipitation of the trapped inorganic ions (including uranyl ion) released from the disrupted EPS by heating. A significant amount of uranium was detected in the EPS solutions extracted using the EDTA method, which accounted for about $42.1 \% \mathrm{TU}$ in the sludge (Fig. 2). This incredible uranium content should be caused by high redissolution extent of insoluble U(Iv) during the EPS extraction process (Fig. 3). As a strong complexation agent, EDTA can dissolve the U(Iv) minerals by forming U(Iv)-EDTA complexes. ${ }^{28}$ For the CER extraction method, the $\mathrm{TU}_{\mathrm{EPS}}$ contents depend largely on the extraction time at the same stirring intensity. The ratio of $\mathrm{TU}_{\mathrm{EPS}} / \mathrm{TU}_{\text {sludge }}$ increased with the extraction time, but the re-dissolution of insoluble $\mathrm{U}(\mathrm{Iv})$ also became severe when the extraction time was prolonged from $1 \mathrm{~h}$ to $2 \mathrm{~h}$ at $600 \mathrm{rpm}$. Comparatively, the extent of U(Iv) re-dissolution was acceptable when the extraction time was $1 \mathrm{~h}$ at $600 \mathrm{rpm}$ (Fig. 3).

Fig. 1 shows the uranium contents in the EPS (expressed as $\mathrm{TU}_{\text {EPS }}$ /Total ${ }_{\text {EPS }}$ ) extracted using different methods. The results indicate that the control, sonication ( $5 \mathrm{~min}$ or $10 \mathrm{~min}$ at $150 \mathrm{~W}$ ), and CER ( $1 \mathrm{~h}$ at $600 \mathrm{rpm})$ methods provided similar values for $\mathrm{TU}_{\mathrm{EPS}} /$ Total $_{\mathrm{EPS}}$, which ranged from 100.1 to $144.0 \mathrm{mg} \mathrm{U}$ per $\mathrm{g}$ EPS. Contrary to other extraction methods, this value range may be closer to the real uranium content in EPS.

Based on the comprehensive consideration of the uranium and EPS extraction efficiency and U(rv) re-dissolution extent 
Table 1 The uranium fractions and their contents and fraction in the AnGS at the beginning and day 13

\begin{tabular}{|c|c|c|c|c|c|c|c|}
\hline \multirow[b]{2}{*}{ Time } & \multicolumn{2}{|c|}{ Anaerobic water } & \multicolumn{2}{|c|}{ Anaerobic $\mathrm{NaHCO}_{3}$} & \multicolumn{2}{|l|}{$\mathrm{HNO}_{3}$} & \multirow[b]{2}{*}{ Recovery /\% } \\
\hline & $\begin{array}{l}\text { Content /mg } \\
\mathrm{U} \text { per } \mathrm{g} \mathrm{SS}\end{array}$ & Fraction $/ \%$ & $\begin{array}{l}\text { Content } / \mathrm{mg} \\
\mathrm{U} \text { per } \mathrm{g} \mathrm{SS}\end{array}$ & Fraction /\% & $\begin{array}{l}\text { Content } / \mathrm{mg} \\
\mathrm{U} \text { per } \mathrm{g} \mathrm{SS}\end{array}$ & Fraction /\% & \\
\hline 0 & $0.01 \pm 0.001$ & $14.3 \pm 3.0$ & $0.03 \pm 0.00$ & $48.2 \pm 2.5$ & $0.02 \pm 0.004$ & $37.5 \pm 5.4$ & $96.2 \pm 5.4$ \\
\hline Day 13 & $0.80 \pm 0.41$ & $2.7 \pm 1.4$ & $12.4 \pm 1.0$ & $41.9 \pm 3.5$ & $16.4 \pm 1.4$ & $55.4 \pm 4.8$ & $92.3 \pm 6.4$ \\
\hline
\end{tabular}

(Table 2 and Fig. 2 and 3), the sonication, heating, and EDTA methods were not suitable for EPS extraction to determine the species and contents of uranium in EPS because of their low uranium extraction efficiency or severe U(Iv) re-dissolution. However, when the CER method was used for EPS extraction, the content of uranium in EPS $\left(14.1 \pm 2.0 \% \mathrm{TU}_{\text {sludge }}\right)$ obtained under the well controlled extraction conditions (70 g CER/g VSS, $600 \mathrm{rpm}, 1 \mathrm{~h}$ ) was more reasonable and reliable due to the low $\mathrm{U}(\mathrm{Iv})$ re-dissolution extent, high uranium extraction efficiency, and low cell lysis extent, as proven previously. ${ }^{\mathbf{8 , 2 4}}$ Moreover, the value of $\mathrm{TU}_{\mathrm{EPS}} / \mathrm{Total}_{\mathrm{EPS}}$ for $\mathrm{CER}(1 \mathrm{~h}$ at $600 \mathrm{rpm})$ (Fig. 2) confirmed the abovementioned conclusion. Then, for the $97 \%$ $\mathrm{U}(\mathrm{vI})$ removal at day 13 using AnGS (Fig. 1), the contributions were $13.7 \%$ and $83.3 \%$ for the EPS and AnGS's bulk, respectively. Actually, a higher fraction of uranium was found in the EPS of the original AnGS, extracted using the CER method of $1 \mathrm{~h}$ at $600 \mathrm{rpm}$, accounting for $62.0 \pm 7.9 \%$ (data not shown). Comparatively, the EPS can reserve a higher fraction of uranium in the lower U(vi)-level system. The non-negligible uranium content in EPS indicated a strong uranium-accumulating ability of EPS when the AnGS immobilized uranium from groundwater.

\subsection{Particulate uranium in the EPS}

As shown in Table 3, some mineral uranium $(>0.22 \mu \mathrm{m})$ in the EPS extracts was intercepted by the membrane filters, with a fraction of $2.4 \pm 0.7 \%$ and $3.7 \pm 0.9 \%$ for the sonication and CER methods, respectively. However, for the EPS extracts after $0.22 \mu \mathrm{m}$ filtration, the particulate uranium was dominant as measured by ICP-MS, accounting for $80.9 \pm 1.8 \%$ and $85.1 \pm$ $2.2 \%$ for the sonication and CER methods, respectively. Upon combining the results of the two parts, it was observed that particulate uranium was the main form of uranium in the EPS. More particulate uranium in the tightly bound EPS was released using the CER method due to higher extraction efficiency of this method towards uranium.

Single particle ICP-MS analysis has been successfully used in the size distribution tests of $\mathrm{TiO}_{2}, \mathrm{ThO}_{2}$, and $\mathrm{UO}_{2}$ colloids. ${ }^{29,30}$ As shown in Fig. 4, large amounts of nano-sized uranium particles were detected using ICP-MS. For the EPS extracts obtained using the sonication method, the size of the uranium particles was in the range from 44.3 to $211.1 \mathrm{~nm}$ (Fig. 4a), whereas for those obtained using the CER method, it ranged from 24.7 to $171.3 \mathrm{~nm}$ (Fig. 4b). The size of the uraniumcontaining particles in the EPS extracts obtained using the CER method (mean size of $46.0 \mathrm{~nm}$ ) was much smaller than that obtained using the sonication method (mean size of $79.5 \mathrm{~nm}$ ); this indicated that smaller uranium colloids occupied the tightly bound EPS. As reported by William et al. (2008), about $3.0 \mathrm{~nm}$ uraninite was formed by Shewanella oneidensis MR-1 and associated with EPS, as revealed by scanning electron

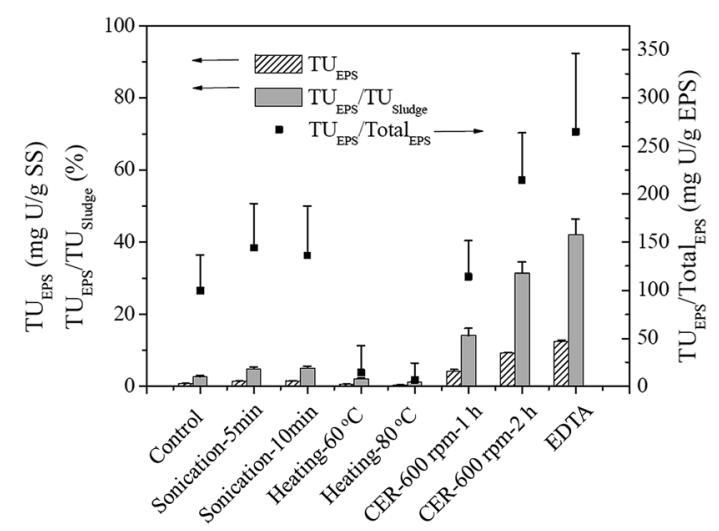

Fig. 2 The TU content, $T U_{\text {EPS }} / T U_{\text {Sludge, }}$ and TU $U_{\text {EPS }} /$ Total $l_{\text {EPS }}$ ratio of the EPS solution extracted from the AnGS.

Table 2 The EPS contents and compositions (mg per g SS) in the EPS solutions extracted from the AnGS-immobilized uranium

\begin{tabular}{|c|c|c|c|c|c|}
\hline Method & Carbohydrates & Proteins & Humic substances & Nucleic acids & Total EPS \\
\hline Control & $2.27 \pm 0.06$ & $2.04 \pm 0.09$ & $0.59 \pm 0.08$ & $3.02 \pm 0.05$ & $7.92 \pm 0.29$ \\
\hline Sonication-5 $\min$ & $2.26 \pm 0.17$ & $3.29 \pm 0.11$ & $1.59 \pm 0.13$ & $2.86 \pm 0.05$ & $10.0 \pm 0.46$ \\
\hline Sonication-10 $\min$ & $2.38 \pm 0.25$ & $4.23 \pm 0.23$ & $0.93 \pm 0.03$ & $3.48 \pm 0.06$ & $11.0 \pm 0.57$ \\
\hline Heating- $60^{\circ} \mathrm{c}$ & $7.27 \pm 0.24$ & $13.5 \pm 0.43$ & $13.2 \pm 0.44$ & $8.33 \pm 0.08$ & $42.3 \pm 1.19$ \\
\hline Heating-80 ${ }^{\circ} \mathrm{c}$ & $10.9 \pm 0.30$ & $18.7 \pm 0.21$ & $10.6 \pm 0.18$ & $12.7 \pm 0.25$ & $52.9 \pm 0.94$ \\
\hline CER-600 rpm-1 h & $8.5 \pm 0.42$ & $5.00 \pm 0.40$ & $14.4 \pm 0.08$ & $8.45 \pm 0.46$ & $36.4 \pm 1.34$ \\
\hline CER-600 rpm-2 h & $13.5 \pm 0.84$ & $9.33 \pm 0.19$ & $9.12 \pm 0.49$ & $11.4 \pm 0.66$ & $43.4 \pm 2.14$ \\
\hline EDTA & $18.8 \pm 0.91$ & $9.61 \pm 1.10$ & $10.4 \pm 1.20$ & $8.11 \pm 0.62$ & $46.9 \pm 3.82$ \\
\hline
\end{tabular}




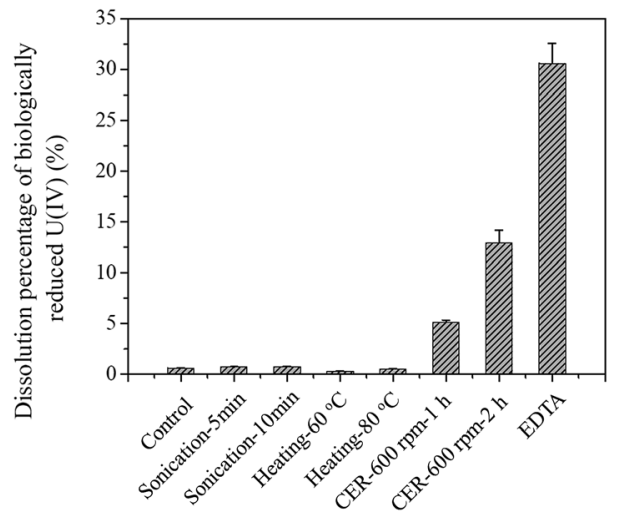

Fig. 3 The dissolution extent of the biologically reduced U(IV) during the extraction process.

microscopy (SEM).$^{31}$ The much larger EPS-associated uranium colloids observed in this study may be due to the accumulation or growth of uranium nuclei with time. Moreover, even solids larger than $0.22 \mu \mathrm{m}$ were present in the EPS.

It should be noted that the particle size obtained by ICP-MS was based on the detection of the signals of elemental uranium and not those of the real uranium-containing solids. While uranium is extremely larger than other element atoms (e.g. oxygen, phosphorus, etc.), its particle size could be very close to the real value.

The abovementioned results suggested that uranium particles were present in the EPS in the form of both micron-size and nano-size particles, which included $\mathrm{U}(\mathrm{vI})$ minerals or U(Iv) minerals, or the both. Although difficult, analysis of the uranium valence states in minerals using SEM coupled with energy dispersive X-ray spectroscopy ${ }^{11,12}$ or other technologies in future investigations is necessary.

\subsection{EPS-induced U(Iv) mineral formation in a $\mathrm{NaHCO}_{3}$ medium}

After $24 \mathrm{~h}$ reaction under anaerobic and aerobic conditions, the EPS extracted from the original AnGS can immobilize $21.9 \pm$ $0.69 \%$ and $18.4 \pm 0.26 \% \mathrm{U}(\mathrm{vI})$ (Table 4), respectively. Hence, bioreduction also contributed to the $\mathrm{U}(\mathrm{vI})$ immobilization, accounting for $15.8 \pm 1.49 \%$ of the $\mathrm{U}(\mathrm{vI})$ totally removed using the AnGS's EPS. The ratio of U(vI) removal via bioreduction in our study was lower than that observed for Shewanella sp. HRCR-1; ${ }^{18}$ this may be attributed to the difference in the active reducing enzyme contents in each EPS due to the excellent ability of dissimilatory metal reduction by Shewanella or the difference in the experimental operations (such as the pre-reduction of EPS by
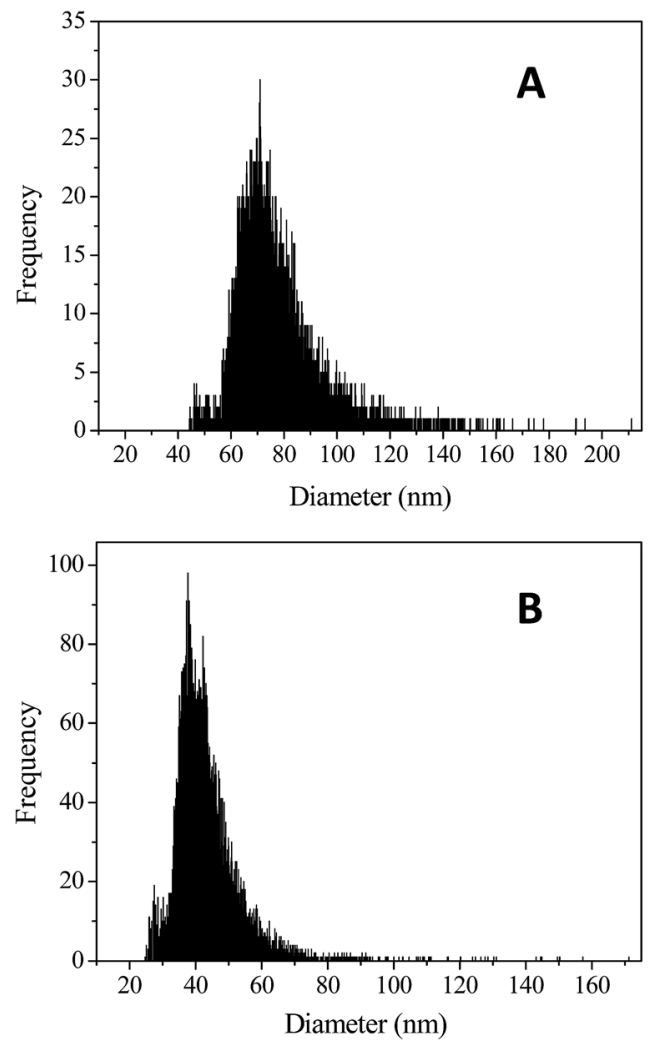

Fig. 4 The size distribution of nano-sized uranium particles in the EPS extracted using the sonication method (A: diluted 100 times, particle concentration of 193756 parts per $\mathrm{mL}$, mean size of $79.5 \mathrm{~nm}$ ) and CER method (B: diluted 1000 times, particle concentration of 169185 parts per $\mathrm{mL}$, mean size of $46.0 \mathrm{~nm}$ ) from AnGS at day 13 (each frequency equals to particle concentration of about 21.2 parts per $\mathrm{mL}$ ).

sodium dithionite in their tests). In addition, since bioreduction is inevitable even under aerobic conditions, bioreduction may be undervalued. Regardless of the different contributions from bioreduction in the uranium immobilization by EPS, two roles including biosorption and bioreduction were confirmed for microbial EPS in uranium remediation.

As indicated by previous studies, cytochrome $\mathrm{C}$ and flavins in EPS obtained from electroactive bacteria, such as Shewanella sp., have shown redox abilities towards metal ions..$^{16,32,33}$ For the EPS of AnGS, UV/visible absorption spectroscopy was used to identify the presence of riboflavin or cytochromes C. The results indicated that cytochrome $\mathrm{C}$ was not detected in the EPS of AnGS. On the other hand, the two peaks at about 225 and $258 \mathrm{~nm}$ (data not shown) may be the characteristic peaks of riboflavin, ${ }^{32}$ implying the presence of extracellular riboflavin in

Table 3 The uranium fractions and their fraction in the EPS solutions extracted using the sonication and CER methods from AnGS at day 13

\begin{tabular}{|c|c|c|c|c|c|c|}
\hline & \multicolumn{2}{|c|}{ Filtration $(>0.22 \mu \mathrm{m})$} & \multicolumn{2}{|c|}{ ICP-MS $(<0.22 \mu \mathrm{m})$} & \multicolumn{2}{|c|}{ Total uranium in EPS } \\
\hline & Soluble $(\%)$ & Particle (\%) & Soluble $(\%)$ & Particle (\%) & Soluble (\%) & Particle (\%) \\
\hline CER-600 rpm-1 h & $96.3 \pm 0.88$ & $3.7 \pm 0.88$ & $14.9 \pm 2.2$ & $85.1 \pm 2.2$ & $14.3 \pm 3.1$ & $85.7 \pm 3.1$ \\
\hline
\end{tabular}


Table $4 \quad U(\mathrm{VI})$ removal by the EPS extracts in a $\mathrm{NaHCO}_{3}$ medium

\begin{tabular}{lllll}
\hline Time & $\begin{array}{l}\text { Anaerobic } \\
\text { removal }(\%)\end{array}$ & $\begin{array}{l}\text { Aerobic } \\
\text { removal }(\%)\end{array}$ & $\begin{array}{l}\text { Adsorption } \\
\text { contribution } \\
(\%)\end{array}$ & $\begin{array}{l}\text { Reduction } \\
\text { contribution } \\
(\%)\end{array}$ \\
\hline $12 \mathrm{~h}$ & $8.12 \pm 0.29$ & $7.05 \pm 0.28$ & $86.8 \pm 0.46$ & $13.2 \pm 0.46$ \\
$24 \mathrm{~h}$ & $21.9 \pm 0.69$ & $18.4 \pm 0.26$ & $84.2 \pm 1.49$ & $15.8 \pm 1.49$
\end{tabular}

the U(vi) reduction process. As indicated by Tapia-Rodriguez et al. (2010), Desulfovibrio and Clostridium spp., known as U(vI)-reducing bacteria, were identified in the AnGS cultured in brewery or related effluents. However, these bacteria could be rare in AnGS, even after stimulation by a high concentration of $\mathrm{U}(\mathrm{vI})$. Therefore, the extracellular cytochromes $\mathrm{C}$ may be too low to be detected or even not present. Interestingly, riboflavin may act as an electron mediator for $\mathrm{U}(\mathrm{vI})$ reduction by EPS. Moreover, humic substances may play roles in the U(vI) reduction process by the EPS of AnGS. ${ }^{33}$

The important roles of EPS in affecting the mobility of uranium in groundwater should deserve more attention. Notably, to simulate real groundwater environments, $1 \mathrm{~g} \mathrm{~L}^{-1} \mathrm{NaHCO}_{3}$ was used as a buffer and complexed with uranyl ions to form uranylcarbonate complexes. Therefore, as compared to the report on the reaction between EPS obtained from Shewanella sp. HRCR-1 and a pure uranyl solution, ${ }^{18}$ this study was closer to the reality occurring in uranium-contaminated groundwater.

\subsection{The implications of this study}

As a permeable hydrogel layer around cells, EPS are the inevitable pathway for mass transfer between microorganisms and the environment. ${ }^{34,35}$ Considering its great ability in uranium accumulation, in situ transformation of soluble $\mathrm{U}(\mathrm{vI})$ to insoluble U(Iv) via bioreduction should be facilitated, which is favorable towards preventing the migration of uranium with groundwater and maintaining the bioactivity of AnGS.

The results of uranium immobilization by AnGS without external electron donors proved the availability of the endogenous substrate, serving as electron donors for uranium bioreduction, which was in accordance with a previous study. ${ }^{23}$ Actually, a considerable part of the endogenous substrate was provided by EPS itself (especially the carbohydrates in EPS) or its degradation. Hence, EPS may also provide electron donors for the U(vi) bioreduction process; this has been observed in $\mathrm{H}_{2}$ production using AnGS when the substrate is in short supply. ${ }^{36}$ To clarify this, monitoring the variation of the contents of carbohydrates, proteins, and humic substances in the EPS during the entire process of uranium immobilization by AnGS is necessary.

Since a strong uranium-accumulating ability was found in the EPS of AnGS (this work) and Shewanella sp. HRCR-1, ${ }^{18}$ the interaction between the EPS and uranium needs further investigation.

\section{Conclusions}

Significant amount of uranium was found in the EPS of AnGStreated uranium-containing groundwater, accounting for 12-
$16 \% \mathrm{TU}_{\text {sludge }}$ (extracted using the CER method with $70 \mathrm{~g} \mathrm{CER/g}$ VSS at $600 \mathrm{rpm}$ for $1 \mathrm{~h}$ ). The results showed that uranium associated with EPS could be present in two forms: the soluble and particulate form. In addition to biosorption, bioreduction also contributed to uranium immobilization by the AnGS's EPS. The significant amount of uranium in the EPS matrix offers a new insight into the characteristics of extracellular uranium in the process of uranium immobilization for groundwater remediation using AnGS.

\section{Conflicts of interest}

The authors declare no competing financial interest.

\section{Acknowledgements}

The authors wish to thank the NSFC $(21407133,21571163$, and 51608498) and the Radiochemistry 909 Program in China Academy of Engineering Physics (CAEP) for providing partial support for this study.

\section{References}

1 W. M. Wu, J. Carley, T. Gentry, M. A. Ginder-Vogel, M. Fienen, T. Mehlhorn, H. Yan, S. Caroll, M. N. Pace, J. Nyman, J. Luo, M. E. Gentile, M. W. Fields, R. F. Hickey, B. Gu, D. Watson, O. A. Cirpka, J. Zhou, S. Fendorf, P. K. Kitanidis, P. M. Jardine and C. S. Criddle, Environ. Sci. Technol., 2006, 40, 3986-3995.

2 S. Sarri, P. Misaelides, D. Zamboulis, L. Papadopoulou and J. Warchoł, J. Radioanal. Nucl. Chem., 2013, 295, 1731-1736.

3 M. Martins, M. L. Faleiro, A. M. R. da Coasta, S. Chaves, R. Tenreiro, A. P. Matos and M. C. Costa, J. Hazard. Mater., 2010, 184, 89-96.

4 L. Newsome, K. Morris and J. R. Lloyd, Chem. Geol., 2014, 363, 164-184.

5 U. Suzuki, H. Mukai, T. Ishimura, T. D. Yokoyama, S. Sakata, T. Hirata, T. Iwatsuki and T. Mizuno, Sci. Rep., 2016, 6, 1-6. 6 A. Tapia-Rodriguez, V. Tordable-Martinez, W. Sun, J. A. Field and R. Sierra-Alvarez, Biotechnol. Bioeng., 2011, 108, 25832591.

7 A. Luna-Velasco, R. Sierra-Alvarez, B. Castro and J. A. Field, Biotechnol. Bioeng., 2010, 107, 933-942.

8 H. L. Zhang, W. Fang, Y. P. Wang, G. P. Sheng, R. J. Zeng, W. W. Li and H. Q. Yu, Environ. Sci. Technol., 2013, 47, 11482-11489.

9 J. Xu, G. P. Sheng, Y. Ma, L. L. Wang and H. Q. Yu, Water Res., 2013, 47, 5298-5306.

10 L. L. Li, Z. H. Tong, C. Y. Fang, J. Chu and H. Q. Yu, Water Res., 2015, 70, 1-8.

11 P. D'Abzac, F. Bordas, E. Joussein, E. van Hullebusch, P. N. L. Lens and G. Guibaud, Environ. Sci. Technol., 2010, 44, 412-418.

12 I. Bourven, E. Joussein and G. Guibaud, Bioresour. Technol., 2011, 102, 7124-7130.

13 A. W. Decho, Ecol. Eng., 2010, 36, 137-144. 
14 Y. M. Lin, J. P. Bassin and M. C. M. van Loosdrecht, Water Res., 2012, 46, 986-992.

15 L. Castro, R. Y. Zhang, J. A. Munoz, F. Gonzalez, M. L. Blazquez, W. Sand and A. Ballester, Biofouling, 2014, 30, 501-511.

16 S. W. Li, X. Zhang and G. P. Sheng, Environ. Sci. Pollut. Res., 2016, 23, 8627-8633.

17 C. C. Li, Y. J. Wang, F. Dang and D. M. Zhou, J. Hazard. Mater., 2016, 308, 21-28.

18 B. Cao, B. Ahmed, D. W. Kennedy, Z. Wang, L. Shi, M. J. Marshall, J. K. Fredrickson, N. G. Isern, P. D. Majors and H. Beyenal, Environ. Sci. Technol., 2011, 45, 5483-5490.

19 L. Macaskie, K. Bonthrone, P. Yong and D. Goddard, Microbiol., 2000, 146, 1855-1867.

20 S. C. Yuan, S. B. Xie, Z. Yan and H. Ling, Municipal Engineering Technology, 2012, 30, 97-100, in Chinese.

21 B. Cao, L. Shi, R. Brown, Y. Xiong, J. Fredrickson, M. Romine, M. Marshall, M. Lipton and H. Beyenal, Environ. Microbiol., 2011, 13, 1018-1031.

22 N. Fernandez, E. E. Diaz, R. Amils and J. L. Sanz, Microb. Ecol., 2008, 56, 121-132.

23 A. Tapia-Rodriguez, A. Luna-Velasco, J. A. Field and R. SierraAlvarez, Water Res., 2010, 44, 2153-2162.

24 B. Frølund, R. Palmgren, K. Keiding and P. H. Nielsen, Water Res., 1996, 30, 1749-1758.

25 D. A. Elias, J. M. Senko and L. R. Krumholz, J. Microbiol. Methods, 2003, 53, 343-353.
26 APHA, Standard methods for the examination of water and wastewater, American Public Health Association, Washington, DC, 1995.

27 J. H. Huang, E. J. Elzinga, Y. Brechbuehl, A. Voegelin and R. Kretzschmar, Environ. Sci. Technol., 2011, 45, 2804-2810.

28 Y. Suzuki, K. Tanaka, N. Kozai and T. Ohnki, Geomicrobiol. J., 2010, 27, 245-250.

29 C. Degueldre and P. Y. Favarger, Colloids Surf., A, 2003, 217, 137-142.

30 C. Degueldre, P. Y. Favarger, R. Rossé and S. Wold, Talanta, 2006, 68, 623-628.

31 D. B. William, J. T. McDonough, J. M. Senko, G. Zhang, A. C. Dohnalkova, S. D. Kelly, Y. Gorby and K. M. Kemner, Geochim. Cosmochim. Acta, 2008, 72, 4901-4915.

32 Y. Xiao, E. Zhang, J. Zhang, Y. Dai, Z. Yang, H. E. M. Christensen, J. Ulstrup and F. Zhao, Sci. Adv., 2017, 3, e1700623.

33 Y. Xiao and F. Zhao, Current Opinion in Electrochemistry, DOI: 10.1016/j.coelec.2017.09.016.

34 S. Wang, M. Gao, Z. Wang, Z. She, C. Jin, Y. Zhao and Z. Li, RSC Adv., 2015, 5, 30737-30747.

35 P. Xia, Q. Li, L. Tan, X. Sun, C. Song and S. Wang, RSC Adv., 2016, 6, 59438-59444.

36 G. P. Sheng and H. Q. Yu, Appl. Microbiol. Biotechnol., 2007, 74, 208-214. 